\title{
The conventionalization of local food: Farm reflections on local, alternative beef marketing groups
}

\author{
Phil Mount ${ }^{\text {a* }}$ \\ Wilfrid Laurier University \\ John Smithers ${ }^{\mathrm{b}}$ \\ University of Guelph
}

Submitted September 30, 2013 / Revised February 6, 2014 / Accepted February 7, 2014 /

Published online April 30, 2014

Citation: Mount, P., \& Smithers, J. (2014). The conventionalization of local food: Farm reflections on local, alternative beef marketing groups. Journal of Agriculture, Food Systems, and Community Development, 4(3), 101-119. http://dx.doi.org/10.5304/jafscd.2014.043.002

Copyright (C) 2014 by New Leaf Associates, Inc.

\begin{abstract}
Across North America, the local food market has been peddled as an alternative or value-added production and marketing niche for small and midscale family farms. Many former commodity farmers are now selling product to local consumers - either on their own, with groups of farmers, as cooperatives, or through intermediaries with active distribution chains.

The literature on the conventionalization of organic suggests that larger farm scale and an intermediary-controlled chain may produce unintended effects for producers in these local markets. The same literature also questions the role

\footnotetext{
a* Corresponding author: Phil Mount, Department of Geography and Environmental Studies, Wilfrid Laurier University;

of farm scale in shaping motivations. Reflections from first-adopters on their experiences in local food marketing channels - both direct-toconsumer and through intermediaries - could provide insight into the effects of "scaling up" and a potential move toward the conventionalization of local food.

In this paper we investigate two models of "local beef" groups that operate in the province of Ontario: one organized by farmers and reliant on direct marketing, and a second, larger-scale model, led by intermediaries that purchase and market the product from farmers. Through an analysis of interviews with farmers, and borrowing from adoption of innovation frameworks, we present in the farmers' words - some of the factors and motivations that attract commodity producers to these two types of marketing innovation, and try to expose the gap between expectations and outcomes. The findings help to gauge how scale of farm and group operation influences results, how 
this relates to processes of conventionalization, and what this means for the future of these local marketing groups.

\section{Keywords}

adoption of innovations, alternative marketing, beef, conventionalization, cooperatives, local food, scaling up

\section{Introduction}

In recent years, diversification and value-added production have emerged as options for farmers hoping to maintain family-scale production in North America. The potential of local food as an alternative niche market has increasingly attracted attention, and many midscale producers are testing this market either through direct sales or through a growing number of alternative marketing and distribution chains serving local consumers.

This trend begs questions not only of commodity farmers' ability to adapt to alternative marketing arrangements, but also of the impacts of increased volumes from these chains on local markets. The literature on organic conventionalization suggests that chains controlled by intermediaries not only drive down prices, they also encourage participation of larger producers whose approach and mindset are ill-suited to alternative markets (Buck, Getz, \& Guthman, 1997). Research capturing the experiences of first-adopters of these new local food markets could provide insight into the potential for conventionalization to influence local food outcomes.

In this paper we investigate two models of "local beef" group marketing chains in the province of Ontario: one organized by farmers and reliant on direct marketing; and a second, largerscale model, led by intermediaries that purchase and market the product from farmers. Through an analysis of in-depth interviews with farmers, and borrowing from adoption of innovation frameworks, we explore the factors and motivations that attract commodity producers to these market innovations; the influence of scale of farm and group operation on their experience; the extent to which conventionalization widens the gap between expectations and outcomes; and what this means for the future of these local marketing groups.

\section{The Problem for Family-scale Farms}

Over the last half century, family farms in the province of Ontario have experienced the impacts of agricultural trends familiar across developed regions of the world, including intensification and specialization of production, and the consolidation of landholdings, pushed forward by a discourse of competition, modernization, and efficiency. At the same time, a combination of overproduction, market and retail consolidation, and global sourcing has produced stagnant commodity prices, a smaller share of a shrinking consumer food dollar, and steadily increasing input costs, resulting in an economic crisis at the farm level. The conventional solution was increased scale, concentration, capital costs, and debt levels (Gray \& Lawrence, 2001; Pierce, 1994) - a productivist treadmill that demanded continual growth without guaranteeing adequate on-farm income (Kloppenburg, 2005; Sparling \& Laughland, 2006). For many farm households, this required levels of debt and investment that were either too risky or unavailable - a situation encapsulated in shorthand by the banking sector's oft-given advice to "get big or get out."

Challenges notwithstanding, many family farms have rejected this fatalistic assessment and have explored diverse development paths (Inwood \& Sharp, 2012; Oerlemans \& Assouline, 2004; Smithers and Johnson, 2004), enabled by a dramatic increase in off-farm labor and income. Over the past generation, off-farm employment in Ontario has gone from occasional supplement to necessary component of household income, now responsible for well over three-quarters of total farm revenue (Agriculture and Agri-Food Canada [AAFC], 2007); almost half of farm operators have an off-farm job or business (Statistics Canada, 2012).

For family-scale farms left behind by commodity systems, value-added differentiation - through new production, processing, or marketing strategies - has been peddled as a cure (Barbieri \& Mahoney, 2009; Stevenson \& Pirog, 2008; Verhaegen \& Van Huylenbroeck, 2001), often in combination with direct marketing. Local food niche markets, which have been growing steadily over the last decade, have attracted much attention 
in this context (Bloom \& Hinrichs, 2011; Inwood \& Sharp, 2012; Stevenson \& Pirog, 2008). By capturing a value-added premium, these alternative strategies promise to reduce the need for off-farm jobs, without demanding a dramatic increase in farm production scales. However, these niche markets have failed to make major inroads in overall market share. Along with limits to the local biophysical and productive resources, and regional infrastructure (Clancy \& Ruhf ,2010; Donald, 2009; Kneafsey, 2010), consistent supply is often listed as a significant barrier to growing local food markets (Jarosz, 2008; Metcalf Foundation, 2008; Ostrom, 2007). These are compounded by difficulties in accessing stable, value-adding alternative food chains (Bloom \& Hinrichs, 2011; Ilbery, Maye, Kneafsey, Jenkins, \& Walkley, 2004; King et al., 2010). Midsized farms with a product that can support local marketing chains stand to reap valueadded benefits, while substantially increasing the volumes currently marketed locally.

However, several factors could influence reorientation to a local food alternative. For transitioning farmers, the new opportunity is not without its costs and risks. Most are unfamiliar with producing and marketing a finished product, either direct-toconsumer or through an alternative marketing and distribution chain. Other possible barriers include a lack of influence and power in new chains, the financial risks of developing alternative marketing activities, and the difficulties of creating alliances with processing, distribution, and wholesaling intermediaries (Ilbery et al., 2004). Collective marketing efforts - including sharing costs, labor, and risk - can minimize some of those barriers and make transition more attractive to farmers (Oerlemans \& Assouline, 2004; Stevenson, 2009; Verhaegen \& Van Huylenbroeck, 2001).

On the other hand, if the transition for largerscale farms is too easy, their approach to production and the increased volumes in local, alternative markets may produce unintended side effects. This warning is an extension of the "conventionalization" thesis, used over a decade ago to describe developments in the organics sector, where the price premium, promises of buyers, strong consumer demand, and weak commodity markets attracted large numbers of conventional producers with no strong ties to the "organics movement" (Buck et al., 1997; Guthman, 2004a). In California, this influx grew organic volumes rapidly, but also diluted the producer pool with those interested only in doing the minimum required to meet organic standards while maintaining industrial production volumes, and continuing to produce conventionally. These large-scale new entrants were less likely to sell direct and, as a result, their profits depended on volume, as their price premium was much lower selling through a buyer, packer, or other intermediary (Guthman, 2004a).

Increased volumes in turn created competition that had not previously existed, forcing all producers to respond to new market imperatives through intensification of production (Guthman, 2004b). This increased the potential for reproduction of conventional food chain outcomes, including loss of small producers (Lockie \& Halpin, 2005) and "the operation of a farm-based cost-price squeeze" (Smith \& Marsden, 2004, p. 355). Falling premiums and a loss of producer control have been recorded in multiple regional markets (De Wit \& Verhoog, 2007; Guptill \& Welsh, 2008; Smith \& Marsden, 2004), driven by oversupply and "oligopolistic positioning" (Smith and Marsden, 2004, p. 356) of retailers in organic supply chains.

This cautionary tale of organic conventionalization is directly relevant to local, alternative markets, since the same ill-defined mix of characteristics that once were applied to "organic" have largely been transferred to "local," including assumptions about smaller farm scales and synergistic benefits that accrue to farmers, consumers, society, and the environment (Friedland, 2008). If growth in the local food market is driven largely by the introduction of largescale producers and groups with more "industrially oriented" philosophies and practices, this has the potential to reproduce the outcomes seen in the organic market, including (a) driving down price premiums and contributing to intensification (Guptill \& Welsh, 2008; Guthman, 2004a), but also (b) decreasing the attention paid to noncommodity benefits that are often loosely articulated yet central to the local food contract. Local markets offer a premium that not only recognizes the tangible and marketable traits of the product and the geographic 
proximity of its production, but also reflects ecological, food security, and food safety outcomes (Bjørkhaug \& Richards, 2008) as well as numerous "intangibles" - from trust and reassurance, to the display of support for local community and farmers (Mount 2012; Verhaegen \& Van Huylenbroeck, 2001).

These noncommodity benefits are more easily acknowledged and exchanged through smallerscale chains that are organized by farmers and reliant on direct marketing. Larger-scale local marketing efforts that forego the interaction required to deliver (and capitalize on) noncommodity benefits to consumers - in favor of increased volume and supply-chain efficiencies - may be more likely to adopt practices that promote oversupply and reproduce commodity-chain relationships with farmers, creating a parallel, conventionalized form of local (Lockie \& Halpin, 2005). But where increased market volumes come from groups of farmers whose only experience is in commodity production, to what extent is conventionalization an outcome of supply-chain scale and dynamics, or the result of the dilution of motivations in the producer pool?

This latter point has long been contested in the organic conventionalization debate. Some contend that, when the market attracts farmers whose primary interest is the price premium, these farmers may be less resistant to processes of conventionalization (Van Huik \& Bock, 2006, in De Wit \& Verhoog, 2007). But evidence supporting this thesis has been uneven (Hall \& Mogyorody, 2001); in their assessment of the conventionalization of organic, Lockie and Halpin (2005) found no motivational differences based on either farm scale or previous involvement in conventional production. Drawing a direct line between motivations and conventionalization is a problematic approach that necessarily simplifies complex motivational profiles (Guthman, 2004a; Lockie \& Halpin, 2005) and minimizes the influences of contextual factors, including farm development path, ease of transition (or "fit"), associated risks, and access to local alternative marketing groups.

In Ontario's beef sector, local and natural have come together to provide an alternative niche opportunity for value-added production and marketing. Many former commodity beef producers are now finishing ${ }^{1}$ and selling natural beef to local customers - either on their own, with groups of farmers, or through intermediaries with active distribution chains. For the purposes of this project, farmers from 27 farms, including 10 couples, were asked to describe their practices before and after joining either direct-marketing or intermediary-led groups; to recall the factors that encouraged them to join; to characterize the nature and function of the group; and to reflect upon their goals and expectations, barriers, satisfaction level, and recommended changes.

Following from a broader research project looking at the effects of scale on the transformations occurring in local food systems (Mount, 2012), in this paper we seek to identify the dissatisfactions, attractions, and fit that encourage farmers who are operating at various scales to become involved in local, alternative beef marketing groups. The analysis delivers a farm-level evaluation of the viability of these groups, paying close attention to how farmers interpret the differences in outcomes produced by the scale and practices of intermediary-led (vs. farmer-led) local marketing chains. This approach will identify gaps between producer expectations and assessments, while also seeking to uncover how the scale of both farm operation and alternative distribution chain interact with contextual factors, motivations, expectations, and evaluations of early-adopting, innovative farmers. Taken together, the perspectives and experiences of producers also shed some preliminary light on the degree and impact of so-called conventionalization in the sector.

In what follows we present a framework for analysis, drawing on adoption of innovation themes and concepts as a way to unpack and systematically investigate the motivations and experiences of farmers. After a brief description of the broader context for decision-making on Ontario beef farms, we describe the research approach and the rationale for categorization of farms, followed by a presentation of the main findings from each category. We conclude by analyzing the influence

\footnotetext{
${ }^{1}$ Finishing is the final stage of livestock rearing, when animals are fattened or fed to a desired weight before slaughter.
} 
of scale and conventionalization on the outcomes described by these farmers, as well as a broad assessment of the possible conventionalization and potential future of these alternative marketing strategies.

\section{Insights from Innovation Adoption}

The challenge of this research involved interpreting reflections from first-adopters on their experiences in local food marketing in order to more thoroughly understand their motivations and expectations, and thereby provide insight into the potential for processes of conventionalization to influence local food outcomes. As mentioned previously, motivations and expectations are framed by a complex set of factors including context, access, fit, and risk. The literature on adoption of innovations offers the tools required to make sense of these decisionmaking processes. While much of this literature in the past has been devoted to understanding the adoption of new technologies or farm production practices (see Röling, 2009), this framework is compatible with the factors that motivate the adoption of alternative marketing strategies.

Local marketing chains delivering value-added product are, by their nature, both alternative and innovative; they force producers to enter into and adapt to new relationships and, often, new production practices. These changes are not made lightly. Family-scale commercial farmers must confront a series of factors that push, pull, and predispose them to look at these alternative marketing strategies. While poor commodity markets and the lure of an expected price premium are important (Barbieri \& Mahoney, 2009), if these two factors alone provided sufficient motivation, alternative chains would be the dominant strategy of struggling family-scale commodity farmers across Ontario. Yet even with the associated risks, expanding conventional production remains a common strategy for family farms in the province. Along with off-farm work, it is the income supplement of choice for all farm development pathways (Potter \& Lobley, 2004; Smithers and Johnson, 2004; Statistics Canada, 2012).

Regional societal and economic forces, commodity markets, and competition all play a role in these decisions, and yet only a small subset of the family-operated farms in Ontario attempts the transition. Clearly it is important to look for other factors that may also be attracting farmers, such as time, existing on-farm income, age, proximity to markets, and marketing skills. At the same time, the priorities, limitations, and goals of the farmer from familial to philosophical to economic - act as filters on these pushing and pulling factors (Barbieri \& Mahoney, 2009; Greiner, Patterson, \& Miller, 2009; Jervell, 1999). Recent research has identified a growing number of farms (particularly at the rural-urban interface) that are turning away from the risks of expansion and debt and toward increasing value-adding from niche production and localization, as well as "enterprise stacking" (multiple products and businesses on the same farm), to increase on-farm viability through diversification, flexibility, and intergenerational engagement (Inwood \& Sharp, 2012).

\section{Relative Advantage}

For some farm families, alternative market innovation may simply be a better fit. Adoption is more likely if farmers are already familiar with the relevant practices (Marra, Pannell, \& Ghadim, 2003; Wejnert, 2002), or have useful knowledge or experience (Prokopy, Floress, Klotthor-Weinkauf, \& Baumgart-Getz, 2008). Likewise an alternative strategy may fit their philosophical or lifestyle goals (Moreland \& Hyland, 2009), or mesh well with the current trajectory of their farm enterprise (Röling, 2009).

The nature of the commitment also influences the "fit," including whether alternative marketing chains are simple to join, participate in, or leave, and possible to try on a small scale. These factors - described in the literature as "complexity," "trialability," and "divisibility" (see for example Moreland \& Hyland, 2009) - help to calculate not only the ease of transition, but also the risks and relative advantage involved with adoption.

These decisions are based on a complex set of interconnected factors (see Table 1) that measures the strengths, weaknesses, and potential of the new practices against those being replaced, resulting in a judgement usefully referred to as the relative advantage (see Greiner et al., 2009; Moreland \& Hyland, 2009). Dissatisfactions, attractions, and predisposi- 
Table 1. Indicators in the Calculation of the Relative Advantage of an Innovation

\begin{tabular}{ll}
\hline Indicators & Factors \\
\hline Motivations & - Dissatisfactions \\
& - Attractions \\
& Predispositions \\
\hline Fit & - Familiarity \\
& - Effective knowledge \\
& - Commitment \\
& Comfort \\
\hline Costs & - Transition costs \\
& - Transaction costs \\
& Operational costs \\
\hline Risk & Risk attitude \\
& O Uncertainty \\
& O Insurance
\end{tabular}

tions push and pull farmers towards these innovations, and are weighed against physical, philosophical, and enterprise "fit" in a calculation of relative advantage.

This calculation is commonly portrayed in the literature as a form of cost-benefit analysis (Lubell, Hillis, \& Hoffman, 2011). Stacked against motivations and fit are the costs, including the transition costs (altered practices) and any known increases in operational costs (new inputs) or transaction costs (new relationships). But this analysis is mediated by the knowledge, intuitions, and perceptions of the farmer, including the estimation of the relative potential returns - both current versus future, and old chain versus new (Marra et al., 2003; Prokopy et al., 2008).

In addition, the likelihood of adoption is influenced by the perception of the risks and uncertainties involved in participation (Greiner et al., 2009; Moreland \& Hyland, 2009), and is mediated by the farmers' attitudes towards risk-taking. These "risk attitudes" are in turn affected by the region and context of the farm (Greiner et al., 2009), as well as any support that could act as insurance and/or mitigate risk (Sunding \& Zilberman, 2001). Familiarity with practices of this alternative will also reduce the perception of risk (Wejnert, 2002). This complex interaction of attitude, risk, and uncertainty is likely to influence not only the decision to adopt, but also the extent or intensity of adoption, reflected in the commitment of the farmer to his or her group (Greiner et al., 2009; Marra et al., 2003).

The overall balance of factors influencing the assessment of relative advantage is captured in an informal determination of the assumed costs, benefits, and risks of joining, balanced against the motivations driving their interest, and the fit of the alternative to the practices and philosophy of the farmer. The weight given to each of these factors, in turn, is influenced by personal priorities: financial versus lifestyle, and short-term versus longterm (Greiner et al., 2009).

While these factors as a whole offer an explanation of why farmers take part in local, alternative marketing strategies, their assessment of the chain's ability to meet their expectations rests on their reassessment of its potential. Farmers' views of the conventionalization or viability of their alternative value-added marketing chains reflects experiences within their local group, comparing expectations and outcomes, tempered by factors that indicate a willingness and ability to adapt to unexpected outcomes.

According to the conventionalization premise, one might expect large, formerly conventional beef farmers to display identifiably different motives and expectations from small-scale producers engaging in local food initiatives as an alternative (see Buck et al., 1997). However, it is necessary to determine the extent to which the farm's scale of operation influences the decision to choose a group with large or small-scale operations, as this may play a role in shaping motives and expectations. For purposes of our own analysis, this represents an important consideration, as the scale of both farm operation and marketing group may play an important role in the farm-level calculation of risks and benefits, the decision to participate, the level of engagement, and the interpretation of results.

\section{Ontario Beef: A Glimpse of the Sector and the Research Sample}

The first decade of the $21^{\text {st }}$ century was not kind to Ontario beef farmers. The vast majority operated small or midsized herds that supplied breeding cattle, calves, and finished animals to the conventional commodity chain. With the loss of most export markets after the discovery of a single 
Canadian $\mathrm{BSE}^{2}$-infected animal in 2003, this commodity chain broke. Beef from the large feedlots of Alberta that were originally destined for export flooded the Ontario market, driving down salebarn and packer prices, causing many of these farmers to hold their cattle, and disrupting the entire chain, except for retail, where prices remained stubbornly fixed (National Farmers Union [NFU], 2008). In the midst of this crisis, Cargill, ${ }^{3}$ a multinational agricultural commodity monolith that already owned large beef-processing facilities in Alberta, purchased Better Beef, a facility in the city of Guelph that processed 80 percent of Ontario's beef. This gave Cargill over 50 percent of Canada's federally inspected fed-cattle slaughter (Standing Committee on Agriculture and Forestry, 2005).

Over the course of the next decade, prices for commodity beef in Ontario slowly rebounded, but not to pre-BSE crisis levels. Many small and midsized beef farmers simply abandoned the sector; between 2001 and 2006, Ontario lost 18 percent of its beef farms (Statistics Canada, 2006). By 2010, a Canada-wide survey of farmers found that 57 percent of beef producers described themselves as "better off" than five years ago (an alltime high number for beef producers), and also that 41 percent would discourage family or friends from a career in primary production (Canadian Cattlemen's Association [CCA], 2011) — a much greater proportion than any other group of farmers. Those who remained were strongly motivated to find alternatives to conventional beef markets and their role as producers of undifferentiated commodities. They were also more inclined to be receptive to the inherent rewards of alternative marketing chains than they might have been prior to the BSE crisis. These realities provide context for the decisions made by farmers in this study.

\footnotetext{
${ }^{2}$ Bovine spongiform encephalopathy (BSE), also known as "mad cow disease," is a fatal neurodegenerative disease that affects cattle and is implicated in the development of variant Creutzfeldt-Jakob disease in humans.

${ }^{3}$ While there are several large multinationals operating in the intensely concentrated industrial beef sector, the largest and most notorious in Ontario is Cargill (see NFU, 2008). For the farmers in this study, "Cargill" often serves as shorthand for industry concentration and market distortion.
}

Table 2. Sample of Alternative Beef Farms in Ontario: Farm Scale X Group Marketing Approach

\begin{tabular}{lccc}
\hline & \multicolumn{3}{c}{ Farm Scale } \\
\cline { 2 - 4 } Alternative & (Animals shipped annually) \\
\cline { 2 - 4 } Marketing Chain & $\mathbf{S}$ & $\mathbf{M}$ & $\mathbf{L}$ \\
\hline Direct & 11 & 5 & 2 \\
\hline Intermediary & - & 7 & 2 \\
\hline
\end{tabular}

\section{The Sample}

Interviews were conducted primarily on-farm, with producers from 27 different farms, including 10 farm couples. The average age was close to the Ontario farm average (approximately 56), with only three respondents under 50. More than half were farming on the family farm, and only six had been farming for fewer than 20 years. Seventeen also worked or had retired from full-time off-farm jobs.

All of the beef sold through these groups was raised as "natural," meaning free of administered hormones or antibiotics. According to our results, the farmers attracted to value-added niche marketing are not a homogeneous cluster, but range in scale from small cow-calf ${ }^{4}$ herds to feedlots.

The sample was categorized according to (1) farm scale and (2) type of alternative marketing chain. For the purposes of this study, farm scale was determined primarily by the number of beef finished on the farm per year (see Table 2). Many of the farms designated as "midsized" actually have large landholdings and secondary agricultural enterprises, including cash crops and diverse livestock. For almost all, beef was the primary focus and largest source of on-farm income. The average beef herd in Ontario has 65 head of cattle (Canfax Research Services [CRS], 2011). Farms finishing fewer than 25 head per year $(n=11)$ were desig-

\footnotetext{
4 "Cow-calf": In the industrialization of the beef chain, the greatest value was given to the "finishing" stage, where cattle are fed to a desired weight before slaughter. As this stage became segregated into feedlots, most small beef herds restricted their operations to breeding, calving, and rearing animals that were sold at "live" auctions to feedlot purchasers. These small herds became known as cow-calf farms. As a result, the growing cohort of farms in Ontario that keep and finish their own animals to sell directly to packers or other customers have become known as "cow-calf-finishers."
} 
nated "small-scale." Those finishing over 100 head per year $(n=4)$ were classified as "large," based on the notion that this level of production demanded full-time focus on finishing (and marketing). The remaining farms, finishing 25-100 per year $(n=12)$, were designated midsized.

Farms were also differentiated according to whether they sold direct to consumer or via an intermediary. The former belonged to one of four small-scale, direct-marketing groups, where producers arranged the processing and were responsible for marketing and retailing. The latter sold finished animals through one of five larger-scale groups organized by intermediaries with an established value-added chain that assumed responsibility for processing, marketing and / or retailing. These intermediaries offer midscale farms one of the few opportunities to access a market for beef produced with alternative practices, by communicating "credence attributes" (such as no hormones/no antibiotics) to consumers (Buskirk, Schweihofer, Rowntree, Clarke, Grooms, \& Foster, 2013). Because of the volumes involved, these intermediaries sought access for their niche products to conventional retail markets, creating a tension between the demands of those markets (higher volumes and slimmer margins) and the farmers' expectations of an alternative market. The details of these groups' activities will be reported elsewhere in the research project.

In the following section, farmers' experiences with and reflections on direct and intermediary-led marketing approaches are analyzed, with careful attention to differences based on the scale of farm operation. For each category, the analysis seeks to capture farmer evaluations of relative advantage as well as their perceptions of barriers and adaptations, results versus expectations, and viability of the alternative marketing chains.

\section{Results}

\section{Direct Marketing Chains}

The four direct marketing groups ship on average between 2 and 20 head per month, and use four different organizational models. The smallest is an informally organized group of like-minded farmers, who deliver boxes of freshly frozen beef, ordered online and via telephone, to customers in central drop-off locations (mostly in the largest regional city) several times per year. Farmers in the other three groups sell directly to consumers through varying combinations of local farmers' markets, restaurants, and small retail and butcher shops. Of these groups, one is a cooperative, another is incorporated and sells under a regional brand, and the third sells through the farm brand of the principal. The latter operates as a sole proprietorship, while the others use consensus-based decision-making.

Just over one-third of all farms in the study were small-scale farms selling direct to consumer. These farms $(n=11)$ contained both the youngest and oldest farmers, including many retired or approaching retirement, and as a result family cycles and farm paths influenced many of the choices on these farms. The farmers from midsized farms $(n=5)$ in this category were largely pragmatic in their expectations. Most continued to ship through conventional channels even after joining an alternative marketing group. For obvious reasons, not many large-scale producers were involved in small, direct-marketing groups. The two exceptions operated small-scale feedlots and had years of experience in finishing and direct marketing. The first sold as much as possible through alternative markets, including a sizeable local freezer beef trade. The second shifted focus from breeding to direct-marketing fresh beef using his farm as a brand. Both were looking for a stable, large-volume alternative to commercial sales.

\section{Relative Advantage}

Poor prices and packer control of the beef market were a large source of dissatisfaction for producers in this category, particularly after the devastating crash of the commodity beef markets following BSE. For these farmers, BSE accelerated a movement away from commodity production and toward niche markets.

The big packers, it doesn't matter on what niche you're aiming for, can squeeze you to death...They can't on local; they can't even really guarantee that it is Canadian beef. So we did that. [D1] 
It is therefore no surprise that these farmers identified better prices and stability (through price and market control) as the principal attractions of the alternative strategies. Most felt that, because these new direct markets required flexibility and perseverance, the local food strategy was beyond the reach of Cargill and major retailers, and gave them favored access to elite consumers who are willing to pay a premium for a high-value product.

Among small-scale farmers, only two had significant experience with both finishing cattle and marketing the beef themselves, as freezer beef. ${ }^{5}$ The majority had minimal or no experience with either finishing or direct-marketing, instead operating as cow-calf producers or breeders ${ }^{6}$ and selling much of their cattle at local auctions on the open market. This was not the case in larger herds, where three of five midscale and both large-scale producers had valuable experience with finishing and direct-marketing, which suggests that effective knowledge may be an important precondition to larger farms' assessment of fit. Several small-scale farmers had recently retired from off-farm jobs, instantly making these alternative groups a better fit. As one such farmer [F11] said, "I would have never tackled it if I were still working." This mirrored a philosophical fit, where most farmers identified a larger purpose for the alternative chains: to support and sustain small farms and the local community through fair prices and working together.

For most, the financial transition costs were minimal, as existing practices met the protocols demanded by the groups. Even for those new to finishing (and purchasing feed) this involved little added expense, as most shipped few beef per year. Many stated that they would not have joined if they thought the chain would involve too much investment of time or money, but also recognized that it would take a significant contribution of time and effort from each group member to make it work.

\footnotetext{
5 "Freezer beef': Beef from cattle that the farmer finishes on the farm, markets, and sells, often by the side (half) or quarter, direct to customers, destined for their freezers.

6 "Breeder": As with plant breeding, a "breeder" raises the seed stock, selected for its genetic characteristics, that other farmers will purchase to improve their herd genetics.
}

We are eliminating the middle man, because each man along the chain claims a piece of the profit - but there also has to be a realization that somebody has to do that work, so if you are going to supply animals to the group you are going to have to do that share of the work...It's not a free ride. [E1]

Many suggested that this expectation had kept some farmers from trying direct-marketing strategies and, similarly, had caused other farmers to leave their groups in the early stages of development. Almost all small-scale farms (but only two midscale farms) relied on diversified income sources (mainly off-farm labor or pensions) as a form of insurance. They felt that by joining a group, their prospects for payment were better than they would be operating alone, while the risk of default would be spread across the group. The calculation of relative advantage in directmarketing chains is summarized in Table 3 .

\section{Alternative Market Viability}

Prices and customer interaction made it worthwhile for most. While the premium was modest, because these groups grew slowly, their small volumes produced low transition costs. At the same time, they could see the benefit of shared labour, expenses and risk, and the relative price advantage. However, most felt that the price premium would be sufficient to sustain only those farms operating at a large scale (most were not).

Most of our members are my age or older, so an expansion really isn't in their way of thinking.... The vast majority — I think three-quarters of them - are retired from their original jobs, or in the process of retiring. [F2]

For those on the retirement path, small volumes with modest profits fit their trajectory. For the rest, the desire for growth had to be balanced against the risk of investment, without the cash flow required to pay full-time marketing or sales staff.

In groups where each member participated in 


\section{Table 3. Relative Advantage in Direct Market Chains}

\begin{tabular}{|c|c|c|}
\hline Indicators & Factors & Examples \\
\hline Motivations & $\begin{array}{l}\text { - } \text { Dissatisfactions } \\
\text { - Attractions } \\
\text { - Predispositions }\end{array}$ & $\begin{array}{l}\text { - } \quad \text { BSE, packer control, farm revenues, off-farm labor, succession } \\
\text { - } \quad \text { Price premium, stability, value-added discourse } \\
\text { farms and local communities }\end{array}$ \\
\hline Fit & $\begin{array}{l}\text { - Familiarity } \\
\text { - Effective knowledge } \\
\text { - Commitment } \\
\text { - Comfort }\end{array}$ & $\begin{array}{l}\text { - } \text { Freezer-beef sales, networked to founding members of group } \\
\text { - } \quad \text { Previous finishing and/or direct-marketing experience } \\
\text { - } \text { Reversibility, low capital requirements, grows own feed } \\
\text { - Philosophical, lifestyle, and enterprise goals }\end{array}$ \\
\hline Costs & $\begin{array}{l}\text { - Transition costs } \\
\text { - Transaction costs } \\
\text { - Operational costs }\end{array}$ & $\begin{array}{l}\text { - Difference in time, effort } \\
\text { - Increased importance, number, investment in relationships } \\
\text { - New inputs (special feed protocol, freezers) }\end{array}$ \\
\hline Risk & $\begin{array}{l}\text { - Risk attitude } \\
\text { o Insurance }\end{array}$ & $\begin{array}{l}\text { - Desperation } \\
\circ \text { Diversification, retirement strategy, shared costs }\end{array}$ \\
\hline
\end{tabular}

decision-making, many identified the timeconsuming nature of meetings as a negative outcome. In one group, a specified feed ration became a particularly negative outcome for those who had expected to grow their own feed. For two of these farmers, discord and unexpected expenses caused them to leave their group, but not alternative marketing: one has since successfully developed a sizable direct-marketing clientele. One helpful transition approach adopted by a small group was selling its members' overflow - for a small premium over commodity prices — to a large, intermediaryled chain, since their practices met its requirements.

Before when I sold my animals I never met the guy who ate the steak, whereas now he is giving you feedback about it. Of course it makes you feel better that you're doing something that someone is happy with; you're doing the right thing, obviously. I think we were doing the right thing before, but we just never heard it. [F8]

While most of the farmers in this category had no previous experience with the consuming public, many quickly learned to appreciate the feedback, satisfaction and validation that came with interaction. With this knowledge and reassurance, it was possible to adapt product lines, packaging, and even production practices in response to consumer concerns and suggestions.
It has to get bigger, or we are done. [D1]

Every farmer in this category identified increased volume as a necessity. However, increased scale demanded increased investment in infrastructure, marketing, and sales. For older couples, their age made them less disposed to longterm, growth-oriented investment.

Everybody else, if they have the equipment and they are young enough and they want to make those investments, well that is perfect. But for us it becomes a hazard. [E2]

All also agreed that consumer price expectations and tastes made it difficult to access the required combination of market share and premium. The barrier in this case was not their existing customers, but finding a strategy that allowed them to access consumers who were not currently looking for alternatives. As a consequence, many referenced the fickle tastes, unchanging habits, and waning engagement of consumers as a marketing barrier.

If we plateau where we are right now I don't know how long we can survive, because you can only ask people to volunteer so much. [F8] 
The number of volunteer hours required of members, especially in the cooperative, led several to suggest that the age of members and volunteer fatigue were also potential barriers and that a paid employee would be required to sustain growth. The co-op used an unexpected revenue surplus from the previous year, along with a small price increase, to hire its first employees. This was part of a conundrum identified by many: despite high work and time commitments, the current price and volume were insufficient to pay for an employee or marketer required to increase volumes. Because they were not selling enough to satisfy their current membership, groups were reluctant to bring in new members to share the workload.

The direct-marketing category was notable for its focus on barriers and adaptations that related directly to the group. However, the mid- and largescale producers in these groups were highly motivated to develop an alternative market that could handle their volume. Some expressed frustration at being forced to continue to use the commodity markets. Many small-scale farmers advocated patient growth, and maintaining existing prices as well as high levels of satisfaction, quality, and standards, and were wary of the added commitments involved with increasing the scale of operations. Those on mid- and large-scale farms pushed for more aggressive strategies, including hiring a new employee, paying for advertising, and trusting that increased sales volumes would pay for both. Others suggested diversified product lines, or operating the abattoir as a community cooperative that, by virtue of its not-for-profit nature, could process local animals at dramatically reduced rates. This would translate into lower prices without affecting the producer premium. ${ }^{7}$

The product will sell itself, we've seen it. But if we don't have counter space it's not going to sell. [D1]

\footnotetext{
${ }^{7}$ Using this approach, diversifying to all meats and producing consistent quality at increased volumes, both the processor and the region's farms could once again become viable, bringing the next generation back to farms - where, currently, there were no prospects for succession.
}

One group developed a "fresh local" niche market, but lack of federal inspection and processing in the region was a barrier to new markets, and shipping livestock hundreds of kilometers for slaughter was simply not an option. For this group, federal inspection is essential, as it would provide access to major retail counter space. Without this, efforts to increase sales through local restaurants and farmers' markets would plateau, as both were reaching saturation points.

On balance, the farmers in this category were happy with their decision to join a direct-marketing group. Difficulty growing the market and high time commitments were recognized as limiting factors, but they were balanced by high price premiums and high satisfaction levels. However, the largescale producers, while largely happy with their experiences and returns, both stated that their scale of operation meant that the inability to increase sales volumes would result in the end of their efforts, and their beef herd.

\section{Intermediary-led Marketing Chains}

The five intermediary-led groups operated at a large scale — all slaughtering over 20 head per week - and used fairly similar organizational models: incorporated, and branded using a regional or quality designation, or the farm brand of the original principal. While each of these groups featured "local" as an element of its marketing strategy, only two sold farm members' beef to consumers through their own retail outlets, while a third sold to customers through large event orders. None of these groups featured direct contact between consumers and farmers, who were simply input suppliers in their value-added chain.

According to group principals, their farmers typically ship over 25 head per year.

The producers working with intermediary chains $(n=9)$ were relatively youthful, with most in their early or mid-50s. Many had at least one family member working full-time on the farm. Two operated as breeding herds; two farms had certified organic acreage (but did not ship organic cattle), while several others had at least contemplated organic production. All were experienced with finishing cattle, and all had - over time shipped to multiple intermediary groups. 
Table 4. Relative Advantage in Intermediary-led Chains

\begin{tabular}{|c|c|c|}
\hline Indicators & Factors & Examples \\
\hline Motivations & $\begin{array}{l}\text { - Dissatisfactions } \\
\text { - Attractions } \\
\text { - Predispositions }\end{array}$ & $\begin{array}{l}\text { - BSE, farm revenues, succession, unfair market competition, } \\
\text { distortion, fluctuation } \\
\text { - } \quad \text { Price premium, stability, value-added discourse } \\
\text { - Control, dignity, innovation }\end{array}$ \\
\hline Fit & $\begin{array}{l}\text { - } \text { Familiarity } \\
\text { - Effective knowledge } \\
\text { - } \text { Commitment } \\
\text { - } \text { Comfort }\end{array}$ & $\begin{array}{l}\text { - } \text { Networked to group members } \\
\text { - } \text { Previous finishing experience } \\
\text { - Reversibility, low capital requirements (midscale) } \\
\text { - Philosophical and enterprise goals }\end{array}$ \\
\hline Costs & $\begin{array}{l}\text { - Transition costs } \\
\text { - Transaction costs } \\
\text { - Operational costs }\end{array}$ & $\begin{array}{ll}\text { - } & \text { Altered feeding practices, cost requirements (large-scale) } \\
\text { - } & \text { Relatively low } \\
\text { - } & \text { New inputs (special feed protocol) }\end{array}$ \\
\hline Risk & $\begin{array}{l}\text { - Risk attitude } \\
\text { o Uncertainty }\end{array}$ & $\begin{array}{l}\text { - Desperation versus resignation } \\
\text { o Failures of other alternative marketing chains }\end{array}$ \\
\hline
\end{tabular}

Relative Advantage

We're not commodity beef producers! [C1]

Most producers were attracted to niche markets as the only option that allowed them to collect a value-added premium and take advantage of the local food opportunity. The midscale producers showed a curiosity, flexibility, and willingness to innovate that made an alternative niche market a good fit.

That really fit our philosophy of farming as well. I'd like to think I'm reasonably innovative, but I mean I'm also very conscious of it being sustainable as well. [B3]

The near-organic producers and the breeders were somewhat sheltered from the effects of the BSE crisis on the live cattle market. The rest expressed dissatisfaction over unfair market competition from subsidized or unregulated imports and captive supply, ${ }^{8}$ which caused fluctuation and a lack of control over prices that affected the ability of farms to adequately plan their operations.

Most midscale producers were already meeting or exceeding natural practices and growing their own feed, which made it fairly easy to match

8 "Captive supply": The operation of large-scale feedlots by packers. This is commonly understood as a mechanism for packers to control supply and regulate the market, and therefore reduce the prices paid to their cow-calf suppliers. expected production protocols. With low transition costs, and transaction costs minimized by sales through a licensed intermediary, farmers felt that these chains could be sampled with minimal risk. But most were also aware of cautionary tales and potential risks of dealing with niche intermediary groups. One of these intermediaries failed amid criminal charges (later dropped), and another struggled through difficulties in adapting to the alternative market (and has since failed).

Both large-scale farms were operated by experienced commodity producers, who saw economic value in typical conventional commoditybeef production practices, including hormone implants and feeding Rumensin ${ }^{\circledR 9}$ and "distillers," a relatively cheap feed byproduct of ethanol production. Because of the transition costs, both anticipated that relatively more work and expense would be required to meet natural protocols. Both were definitely attracted by the premium; in fact, one stated that his business model would not be viable without the premium. The calculation of relative advantage in intermediary-led marketing chains is summarized in Table 4.

\section{Alternative Market Viability}

You are really still dealing with commodity beef and these guys...have substantial

\footnotetext{
${ }^{9}$ Rumensin ${ }^{\circledR}$ is an antibiotic administered in pre-mixed feed rations that allows cattle to eat and convert more grain, more rapidly — and is therefore marketed as a growth-promoter.
} 
overhead costs, so they can't afford to pay you very much. [B4]

But they always find a way of getting their products a little cheaper, so they can make a little bit more profit margin on their end. They say they have to be more competitive in the pricing at their end, which is a whole lot of malarkey. [B5]

Producers in this category were not reticent to express dissatisfaction with their involvement. While they were confident that they produced high quality, consistent animals that generated a profit for the intermediary, most felt the premium that they received was insufficient to reflect this, and based on an unfair split of the consumer dollar. At the time of the interviews, all of these intermediary groups but one offered a premium that floated above the commercial price and therefore still reflected commodity prices, ${ }^{10}$ which many described as artificial and fluctuating. Even with the premium, their rates remained lower than the historic commercial price - that is, still too low to sustain viable farms of their size.

I don't think you should be paid on commodity beef, to me...there should be enough market differentiation it should be a commodity on its own and not be based on the price of commodity beef. [B3]

All groups also reduced their payments to farmers using criteria to regularly claw back the expected premium with weight and grading penalties at slaughter. Their farmers felt that the penalties had less to do with the quality of the animals shipped and more to do with the growing numbers of "natural" producers and cattle, providing a ready pool of alternative supply. Finally, producers often had to wait for payment; proactively cover themselves through what they described as an inadequate provincial government insurance plan; or, as happened to more than one, absorb thousands or

\footnotetext{
10 The exception was a group offering a fixed rate that was often slightly higher (but occasionally lower) than its competition.
}

tens of thousands of dollars lost to nonpayment.

We've even considered forming an association to try and put some kind of captive supply on these guys [intermediaries] — to raise the bar, instead of being dictated to. [B2]

We talked about setting up a Natural Beef Association (like they have in pigs)....We need organization, because numbers is power. [A3]

As a general conclusion, these producers felt that alternative chains show the same tendencies as packers in commodity chains: greed, control, and manipulation. With a price based on the commercial rate, similar relationships, and lack of control, it was clear to them that they were still part of a commodity chain. One large-scale operator, after trying several chains, selected and stuck with one intermediary chain with a stable base rate and lower discounts - both factors that made for more predictable planning. However, the second large-scale operator reflected the norm, preferring the flexibility of choosing from multiple chains as insurance against being in the control of any one group, even though he would prefer to stick with one.

These farmers also identified several barriers beyond their chain, including a lack of public advocacy and education about the high quality standards for beef production in the province, and a need for the rules and regulations that are applied to domestic producers to also be applied equally and rigorously to imports. Producers who had lost money due to nonpayment by intermediary groups also identified inadequate government support and insurance as barriers.

They tell us that we should be doing "value-added," more specialty products, but then they don't offer protection when you do. When you think back to ' 07 and '08, this is what [the Ministry of Agriculture, Food and Rural Affairs (OMAFRA)] was pushing: the "value chains," "niche markets," "branding".... 
And here, you have people that are taking the initiative, and you provide no support! [B4]

After losing thousands of dollars when one intermediary group failed and discovering that the financial protection plan offered by OMAFRA would not cover his losses, one producer started faithfully recording and reporting every transaction in order to guarantee insurance coverage.

There will be successes in some niches ...but there won't be enough of a paradigm shift to keep the industry afloat. [B2]

In their overall assessment, these producers thought that consumption of natural products would surpass organic because of the price differential, and that both niches, while viable, can not compete with mainstream because they are too similar to commodity chains. In fact, one felt that the similarity would spell the end of the natural beef chains in Ontario, as commodity producers and packers would soon flood the market with natural beef from Alberta, produced on a massive feedlot scale. While there were calls for large-scale, systemic responses, including two who suggested some form of supply management for beef, all identified the need to take advantage of the consumer demand for local. Two were drawn to direct sales as the only way to capture the full premium. Others saw the value of local, direct sales, but thought that smaller local or regional intermediary groups held the solution, perhaps by developing regional brands, producer coops, or value chains with local producers and abattoirs.

\section{Discussion: Local Alternative Marketing Chains and the Influence(s) of Scale}

The viability and effectiveness of local food initiatives are in many ways shaped by the expectations and aspirations of the participants. This is particularly the case in local Ontario beef initiatives, where the history of involvement in the commodity beef chain both informs farmers' optimism and tempers their interpretation of outcomes. While neither type of value-added marketing chain explored in this research could be described as unambiguously

\section{Table 5. Key Findings by Market Category}

\begin{tabular}{|c|c|}
\hline Chain & Assessment \\
\hline $\begin{array}{l}\text { Direct- } \\
\text { marketing }\end{array}$ & $\begin{array}{l}\text { - Combination of premium and vol- } \\
\text { - Umes not enough } \\
\text { - Urgent focus on developing markets } \\
\text { - Significant changes required for } \\
\text { increased sales, but insufficient } \\
\text { volumes to pay for expenses of } \\
\text { growth } \\
\text { - Consumer as barrier to growth }\end{array}$ \\
\hline Intermediary & $\begin{array}{l}\text { - Dissatisfaction with conventional } \\
\text { approach, practices of intermediaries } \\
\text { - Niche not producing adequate returns } \\
\text { to producers of high quality beef } \\
\text { - Alternative to intermediary-led chains } \\
\text { required } \\
\text { - Little optimism for future of alterna- } \\
\text { tive niches }\end{array}$ \\
\hline
\end{tabular}

successful (see Table 5), the two models - marketing through an intermediary, and direct marketing - are very different innovations, with different natures and functions, and producing significantly different outcomes for their farmers.

\section{Direct Marketing: Increased Commitment, Inadequate Volumes}

Costs in both labor and time were high for directmarketing farmers, but not unexpectedly so. And these costs were balanced by tangible benefits in shared labor, time, and expenses, a reasonable price premium, and unexpected new skills, confidence, validation, and loyalty from their interaction with consumers. Of course, their group's approach to sharing, pricing, and expenses directly influenced the satisfaction levels of individual farmers. But the primary barrier for direct-marketing farmers, at all scales of farm operation, was the difficulty accessing and expanding their markets to provide fulltime, on-farm incomes. Almost all voiced a desire to sell all of their beef through the chain, reflecting a combination of both financial need and a universal wish to see the group survive and thrive. This attachment to group fortunes was a dominant theme among all direct marketing groups, which meant that farmers of different scales, but sharing the same direct marketing groups, often identified similar barriers and delivered similar assessments. One notable difference was the willingness of 
larger farms in these groups to take an aggressive path that would increase group scale and deliver new markets.

The balance between group scale and growth in markets is critical, and there is a gulf between the volumes, coordination, and capital required for direct markets versus large retail contracts. But even growing small, direct markets requires investment, and without established midscale direct marketing infrastructure (e.g., food hubs) it can be difficult to find enough volume in direct markets to satisfy group needs (see for example the Tallgrass Co-op story in McCann \& Montabon, 2012).

On the whole, those who have chosen the direct-marketing strategy identify more strongly with their group, take more satisfaction from the group's achievements, are committed to finding solutions that will improve their group's performance, and reflect more positively on their experiences. Most notable is the unwavering commitment of the farmers to local direct marketing as the only viable model for family-scale beef farms and the universal acknowledgement that they are not there, yet.

\section{Intermediaries: Value-Added Chain, Conventional Results}

The farmers who chose to market through intermediaries were flexible innovators seeking valueadded opportunities as a way to keep their farms viable. While these farmers were far more likely than the direct-marketers to suggest structural and policy changes that would support the beef sector in Ontario, many identified philosophically as "alternative" - developing practices and genetics that separated them from commodity beef producers. These farmers were searching for a stable, value-added market whose prices reflected their efforts at distinction. What intermediary-led groups offered was operational fit and very little additional expense or changes in practices, except for those producing at the very largest scale. With low transition costs and low expected costs, the nature and function of the intermediary groups (which absorbed many transaction costs) encouraged dabbling.

But the same factors that produced an easy transition also reproduced the conditions of the conventional commodity chain, which led to high producer dissatisfaction. This did not put them off alternative local marketing as a strategy. Instead, their dissatisfaction focused on the flaws of an intermediary model that did not transcend the conventional commodity chain, but merely replaced it.

In place of their current intermediaries, some farmers suggested local, direct markets as an option, while others looked to smaller-scale, regional intermediary groups as a potential model, with more responsiveness and perhaps even direct control by farmers. For these farmers, an affinity for similarly situated farms made an intermediaryled group the better option, as it offered better potential for large-scale marketing. In fact, both midscale and large-scale farmers had taken part in informal discussions investigating the regional intermediary option, but saw the need for consumer education and a lack of direct-marketing experience as serious barriers. While dissatisfaction was high and optimism low, all of these farmers continued in alternative markets as their last, best hope in a broken beef sector.

\section{Lessons and Conclusions}

All of the farmers in this study looked to local, alternative markets as an antidote to the commodity beef markets, particularly following the BSE crisis of 2003. While reflecting many different farm paths (retirement, contraction) and approaches (mixed farms, cow-calf-finishers, feedlots), almost all were looking for a viable method of extracting their products from the unpredictable commodity beef marketplace. And irrespective of farm or group scale, the price premium that resulted from producing for local, niche markets was the primary attraction. Even given the unpredictable nature of the current conventional beef market, there is a case to be made that many of these farmers would have continued in conventional production in the absence of the BSE crisis. At the same time, having been forced to adapt to circumstance, it is equally true that most are now actively seeking an alternative that provides not only an increase in price, but also an increase in producer control.

But, much like previous assessments of transitioning organic producers, attempting to parse farmer motivations beyond these broad strokes can 
be misleading. For several farms, the beef group represented an accessible regional alternative, rather than a philosophical choice. If multiple alternative marketing initiatives had been available in these regions, some would undoubtedly have selected a different type of group. This point is reinforced by the fact that some who shipped through intermediary chains also had a sizeable, direct-marketed "freezer-beef" trade. At the same time, most shipping through intermediaries had little experience with —or desire to learn — direct marketing, particularly given their production volumes. These farms were undoubtedly drawn to their groups because transition to these alternative marketing chains required so little change in farm practices, inputs, or volumes. While this may appear to indicate a more pragmatic set of motivations than farmers who chose direct marketing as a means of eliminating intermediaries from their supply chain, this conclusion begs the question of whether the reduced production volumes of smallscale farmers "freed" them to hold a philosophical position that was otherwise untenable.

Similarly, while all farms produced for a "natural" market, there was a clear line between farmers who sold direct ("that's how we had always raised them, anyway"), and farmers who sold through intermediary-led groups: several of the latter had changed their practices, adopting a feeding program that helped them achieve weight gain and production efficiency targets that were equal or superior to conventional finishing practices. But it is unclear whether this reflects a philosophy tied to conventional scales of production or an alternative, "first-adopter" mindset, willing to push the frontiers of farm practices.

What is also unclear is the relationship between scale of farm operation and the farmer's choice of marketing groups. The largest-scale farms showed a preference - and two were specifically tailored — for the advantages offered by their style of marketing group. But many farmers "chose" their marketing chain based on what was available in their region. The dissatisfactions and motivations of midscale producers are not dissimilar to small-scale producers, which is hardly surprising, since many of the latter were midscale producers on a retirement or disinvestment path. Several of those shipping through intermediaries expressed the intent to switch to direct marketing - for greater control, a larger premium, and more direct contact with the consumer. The rest indicated a preference for the advantages that an intermediary offers, but this may simply reflect the fact that few direct-marketing groups existed in their region.

With few exceptions, all of these farmers inhabit, or at least intimately understand, a modern family-scale farming lifestyle, with the family's main source of income (their off-farm jobs) far more central to decision-making than their farm's struggles on the margins of the commodity beefproduction sector. This marginalization reinforces and is reinforced by the almost universal absence of succession prospects on participating farms. These factors affect the ability to attribute farmers' motivations (their dissatisfactions, attractions, and predispositions) to the scale of their farm operations.

The differences in outcomes, as reported by the farmers themselves, offer the most insight into their mindset. For example, the price premium was a universal attraction, and in relative terms the returns for farmers of both types of marketing chain were fairly similar, given the different levels of effort and risk involved. Yet there were stark differences in interpretations of these outcomes, directly related to the chosen type of marketing chain.

Small-scale direct-marketing groups changed the prices paid to farmers infrequently, some as little as once per year. All but one of the intermediary groups had a premium that floats above the commercial price, which fluctuates weekly. Precise comparisons of farm returns (i.e., per pound) between the two types of marketing groups would require access to long-term price figures for both. Based on an informal running comparison at the time of the study, however, farmers in the direct marketing groups averaged 10-15 percent higher returns. Whether this margin is adequate compensation for their greater time (and often monetary) investment is a question worth exploring.

Yet it was the farmers in intermediary-led chains who were dissatisfied, mainly because the practices and relationships of their intermediary reproduced a set of all-too-familiar, conventional 
outcomes. For those who specifically criticized the market-distorting tendencies of large packers, the direct comparison to the practices of their "alternative" marketing chain is indicative of the disillusionment produced by the conventionalization of these chains. Farmers clearly identified — and rejected as illegitimate - these practices, while still looking for local marketing outlets. Farmer members see intermediary-led chains in their current form as a marginal source of added value with little staying power, but not a true alternative to conventional markets (which they mimic).

This research captures a snapshot of the motivations and experiences of a sample of beef farmers who have transitioned from commodity to alternative, local markets in Ontario, by joining groups with like-minded producers. Their assessments reflect their regional and farm contexts, including the peculiarities of the groups with which they were affiliated. Further research with local marketing chains across North America is needed to clarify whether the conventionalization seen in intermediary-led chains is an inevitable outcome in alternative markets (see Bloom \& Hinrichs, 2011), or if the cooperative and value chain practices common to small-scale, direct-marketing groups can be replicated in large-scale local chains.

\section{References}

Agriculture and Agri-Food Canada [AAFC]. (2007). An overview of the Canadian agriculture and agri-food system 2007. Ottawa: Author. Retrieved from http://www.agr.gc.ca/

Barbieri, C., \& Mahoney, E. (2009). Why is diversification an attractive farm adjustment strategy? Insights from Texas farmers and ranchers. Journal of Rural Studies, 25(1), 58-66. http://dx.doi.org/10.1016/j.jrurstud.2008.06.001

Bjørkhaug, H., \& Richards, C. A. (2008). Multifunctional agriculture in policy and practice? A comparative analysis of Norway and Australia. Journal of Rural Studies, 24(1), 98-111. http://dx.doi.org/10.1016/j.jrurstud.2007.06.003

Bloom, J. D., \& Hinrichs, C. C. (2011). Moving local food through conventional food system infrastructure: Value chain framework comparisons and insights. Renewable Agriculture and Food Systems, 26(1), 13-23.
http://dx.doi.org/10.1017/S1742170510000384

Buck, D., Getz, C., \& Guthman, J. (1997). From farm to table: The organic vegetable commodity chain of northern California. Sociologia Ruralis, 37(1), 3-20. http://dx.doi.org/10.1111/1467-9523.00033

Buskirk, D. D., Schweihofer, J. P., Rowntree, J. E., Clarke, R. H., Grooms, D. L., \& Foster, T. P. (2013). A traceability model for beef product origin within a local institutional value chain. Journal of Agriculture, Food Systems, and Community Development, 3(2), 33-43.

http://dx.doi.org/10.5304/jafscd.2013.032.007

Canada. Parliament. Standing Committee on Agriculture and Forestry. (2005). Cattle slaughter capacity in Canada: Interim report. Retrieved from http://www.parl.gc.ca/Content/SEN/Committee/ 381/agri/rep/repintmay05-e.htm\#2.\%C2\%A0\% C2\%A0\%C2\%A0\%C2\%A0\%C2\%A0 Canadian Beef Import Policy

Canadian Cattlemen's Association [CCA]. (2011, February 7). Beef producer optimism rebounds — survey says [Press release to Farms.com]. Retrieved from http://www.farms.com/FarmsPages/ENews/New sDetails/tabid/189/Default.aspx?NewsId=38666

Canfax Research Services [CRS]. (2011, May). Cycle indicators \& heifer retention [CRS cow/calf special edition fact sheet]. Retrieved from http://www. canfax.ca/Samples/Cycle $\% 20$ Indicators $\% 20 \% 20$ Heifer\%20Retention\%20May\%202011.pdf

Clancy, K., \& Ruhf, K. (2010). Is local enough? Some arguments for regional food systems. Choices, 25(1). http://www.choicesmagazine.org/magazine/ article.php?article $=114$

De Wit, J., \& Verhoog, H. (2007). Organic values and the conventionalization of organic agriculture.

NJAS - Wageningen Journal of Life Sciences, 54(4), 449_ 462. http://dx.doi.org/10.1016/S1573$\underline{5214(07) 80015-7}$

Donald, B. (2009). From Kraft to craft: Innovation and creativity in Ontario's food economy [Ref. 2009-

WPONT-001]. Toronto: Martin Prosperity Institute, Rotman School of Management, University of Toronto. Retrieved from http://martinprosperity.org/media/pdfs/From Kraft to Craft-B Donald.pdf

Friedland, W.H. (2008). 'Chasms' in agrifood systems: rethinking how we can contribute. Agriculture and Human Values, 25(2), 197-201. 
Gray, I., \& Lawrence, G. (2001). A future for regional Australia: Escaping global misfortune. Oakleigh, Australia: Cambridge University Press.

Greiner, R., Patterson, L., \& Miller, O. (2009). Motivations, risk perceptions and adoption of conservation practices by farmers. Agricultural Systems, 99(2-3), 86-104. http://dx.doi.org/10.1016/j.agsy.2008.10.003

Guthman, J. (2004a). Agrarian dreams: The paradox of organic farming in California. Berkeley: University of California Press.

Guthman, J. (2004b). The trouble with 'organic lite' in California: A rejoinder to the 'conventionalisation' debate. Sociologia Ruralis, 44(3), 301-316. http://dx.doi.org/10.1111/j.1467-9523.2004. 00277.x

Guptill, A., \& Welsh, R. (2008). Is relationship marketing an alternative to the corporatization of organics? A case study of OFARM. In T. A. Lyson, G. W. Stevenson, \& R. Welsh (Eds.), Food and the mid-level farm: Renewing an agriculture of the middle (pp. 55-78). Cambridge, Massachusetts: MIT Press. http://dx.doi.org/10.7551/mitpress/97802621229 93.003.0004

Hall, A., \& Mogyorody, V. (2001). Organic farmers in Ontario: An examination of the conventionalization argument. Sociologia Ruralis, 41(4), 399-422. http://dx.doi.org/10.1111/1467-9523.00191

Ilbery, B., Maye, D., Kneafsey, M., Jenkins, T., \& Walkley, C. (2004). Forecasting food supply chain developments in lagging rural regions: Evidence from the UK. Journal of Rural Studies, 20(3), 331-344. http://dx.doi.org/10.1016/j.jrurstud.2003.09.001

Inwood, S. M., \& Sharp, J. S. (2012). Farm persistence and adaptation at the rural-urban interface: Succession and farm adjustment. Journal of Rural Studies, 28(1), 107-117. http://dx.doi.org/10.1016/j.jrurstud.2011.07.005

Jarosz, L. (2008). The city in the country: Growing alternative food networks in metropolitan areas. Journal of Rural Studies, 24(3), 231-244. http://dx.doi.org/10.1016/j.jrurstud.2007.10.002

Jervell, A. M. (1999). Changing patterns of family farming and pluriactivity. Sociologia Ruralis, 39(1), 100-116. http://dx.doi.org/10.1111/1467$\underline{9523.00095}$

King, R. P., Hand, M. S., DiGiacomo, G., Clancy, K.,
Gómez, M. I., Hardesty, S. D.,... McLaughlin, E. W. (2010). Comparing the structure, size, and performance of local and mainstream food supply chains [Economic Research Report No. ERR-99]. Washington, D.C.: United States Department of Agriculture, Economic Research Service. Retrieved from http://www.ers.usda.gov/publications/erreconomic-research-report/err99.aspx

Kloppenburg, J. R., Jr. (2005). First the seed: The political economy of plant biotechnology, 1492-2000 [2nd Ed.]. Madison, Wisconsin: University of Wisconsin Press.

Kneafsey, M. (2010). The region in food - Important or irrelevant? Cambridge Journal of Regions, Economy and Society, 3(2), 177-190. http://dx.doi.org/10.1093/cjres/rsq012

Lockie, S., \& Halpin, D. (2005). The 'conventionalisation' thesis reconsidered: Structural and ideological transformation of Australian organic agriculture. Sociologia Ruralis, 45(4), 284-307. http://dx.doi.org/10.1111/j.14679523.2005.00306.x

Lubell, M., Hillis, V., \& Hoffman, M. (2011). Innovation, cooperation, and the perceived benefits and costs of sustainable agriculture practices. Ecology and Society, 16(4), 23. http://dx.doi.org/10.5751/ES-04389-160423

Marra, M., Pannell, D. J., \& Ghadim, A. A. (2003). The economics of risk, uncertainty and learning in the adoption of new agricultural technologies: Where are we on the learning curve? Agricultural Systems, 75(2-3), 215-234. http://dx.doi.org/10.1016/ S0308-521X(02)00066-5

McCann, N., \& Montabon, F. (2012). Strategies for accessing volume markets in the beef industry: A review of three cooperative business models. Journal of Agriculture, Food Systems, and Community

Development, 2(2), 37-49. http://dx.doi.org/10.5304/jafscd.2012.022.014

Metcalf Foundation. (2008). Food connects us all: Sustainable local food in southern Ontario. Toronto: George Cedric Metcalf Charitable Foundation. Retrieved from http://metcalffoundation.com

Moreland, H., \& Hyland, P. (2009, December). Innovation adoption and fit, linking R\&D and industry. Paper presented at the 23rd Annual Australia and New Zealand Academy of Management Conference (ANZAM 2009), Southbank, Melbourne. Retrieved from http://eprints.qut.edu.au/29139/ 
Mount, P. (2012). Growing Local Food: Scale and local food systems governance. Agriculture and Human Values, 29(1), 107-121.

National Farmers Union [NFU]. (2008). The farm crisis and the cattle sector: Toward a new analysis and new solutions. Saskatoon, Saskatchewan: Author. Retrieved from http://www.nfu.ca

Oerlemans, N., \& Assouline, G. (2004). Enhancing farmers' networking strategies for sustainable development. Journal of Cleaner Production, 12(5), 469-478. http://dx.doi.org/10.1016/S09596526(03)00105-7

Ontario Ministry of Agriculture, Food and Rural Affairs [OMAFRA]. (2009). Farm operators' income from farm and off-farm sources, by region, 2006. Retrieved January 18, 2012, from http://www.omafra.gov.on.ca/ english/stats/finance/reginc06.htm

Ostrom, M. R. (2007). Community supported agriculture as an agent of change: Is it working? In C. C. Hinrichs \& T. A. Lyson (Eds.), Remaking the North American food system: Strategies for sustainability (pp. 99-120). Lincoln, Nebraska: University of Nebraska Press.

Pierce, J. T. (1994). Towards the reconstruction of agriculture: Pathways of change and adjustment. Professional Geographer, 46(2), 178-190. http://dx.doi.org/10.1111/j.00330124.1994.00178.x

Potter, C., \& Lobley, M. (2004). Agricultural restructuring and state assistance: Competing or complementary rural policy paradigms? Journal of Environmental Policy and Planning, 6(1), 3-18. http://dx.doi.org/10.1080/1523908042000259659

Prokopy, L. S., Floress, K., Klotthor-Weinkauf, D., \& Baumgart-Getz, A. (2008). Determinants of agricultural best management practice adoption: Evidence from the literature. Journal of Soil and Water Conservation, 63(5), 300-311. http://dx.doi.org/10.2489/jswc.63.5.300

Röling, N. (2009). Pathways for impact: Scientists’ different perspectives on agricultural innovation. International Journal of Agricultural Sustainability, 7(2), 83-94. http://dx.doi.org/10.3763/ijas.2009.0043

Smith, E., \& Marsden, T. (2004). Exploring the limits to growth' in UK organics: Beyond the statistical image. Journal of Rural Studies, 20(3), 345-357. http://dx.doi.org/10.1016/S0743-0167(03)00044-5
Smithers, John and Paul Johnson. (2004). The dynamics of family farming in North Huron County Ontario: Part I. Development trajectories. The Canadian Geographer, 48 (2), 191- 208.

Sparling, D., \& Laughland, P. (2006). The two faces of farming. Guelph, Ontario: Institute of Agri-Food Policy Innovation. Retrieved from http://sites.ivey.ca/agri-food/files/2009/09/ TwoFacesOfFarming.pdf

Statistics Canada. (2006). Table 3.2: Farms by industry (North American Industry Classification System), Canada and provinces, census years 2001 and 2006 (Ontario). Census of Agriculture. Retrieved from http://www.statcan.gc.ca/pub/95-632x/2007000/t/4129754-eng.htm\#35

Statistics Canada. (2012). Ontario led in soybeans and corn area. Retrieved May 15, 2012, from http://www.statcan.gc.ca/pub/95-640-x/2012002eng.htm

Stevenson, G. W., \& Pirog, R. (2008). Values-based supply chains: Strategies for agrifood enterprises of the middle. In T. A. Lyson, G. W. Stevenson, \& R. Welsh (Eds.), Food and the mid-level farm: Renewing an agriculture of the middle (pp. 119-143). Cambridge, Massachusetts: MIT Press. http://dx.doi.org/

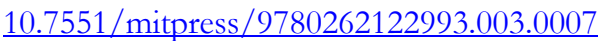

Stevenson, S. (2009). V alues-based food supply chains: Country Natural Beef. Madison, Wisconsin: Center for Integrated Agricultural Systems, University of Wisconsin. Retrieved from the Agriculture of the Middle website: http://www.agofthemiddle.org/ pubs/cnbcasestudyrev012711.pdf

Sunding, D., \& Zilberman, D. (2001). The agricultural innovation process: Research and technology adoption in a changing agricultural sector. In B. L. Gardner \& G. C. Rausser (Eds.), Handbook of Agricultural Economics (Vol. 1, Part A, pp. 207-261). http://dx.doi.org/10.1016/S1574-0072(01)10007-1

Verhaegen, I., \& Van Huylenbroeck, G. (2001). Costs and benefits for farmers participating in innovative marketing channels for quality food products. Journal of Rural Studies, 17(4), 443-456. http://dx.doi.org/10.1016/S0743-0167(01)00017-1

Wejnert, B. (2002). Integrating models of diffusion of innovations: A conceptual framework. Annual Review of Sociology, 28, 297-326. http://dx.doi.org/ $\underline{10.1146 / a n n u r e v . s o c .28 .110601 .141051}$ 